\title{
The Inability Analysis of Catholic Education Institutions on Funding School Operational Especially Regarding Teacher Salaries in Medan
}

\author{
Dionisius Sihombing1, Pastor Daniel Erwin Manullang² \\ ${ }^{1}$ Management lecturer in Medan State University, Indonesia \\ ${ }^{2}$ Archdiocese Education Commission Medan, Indonesia \\ b4hkul.4m4l@gmail.com
}

\begin{abstract}
The purpose of this study is to describe the inability of Catholic education institutions on funding school operations especially regarding teacher salaries in Medan. The main task of the teacher is to do educational assignments. Even though it is not optimal, the cooperation and commitment of all parties involved, especially the institution and the school parties are needed in terms of designing and realizing various collaborative efforts with the church and parents, so that new students will grow in Catholic schools. This study is conducted by using descriptive qualitative approach. The result shows that there is no good achievement without hard work and sacrifice and also a good work approach strategy. Therefore there must be good meetings that create a positive attitude and a sense of belonging to the school, where if the school is successfully developed, all parties will feel the benefits.
\end{abstract}

Keywords : Catholic education institutions; school operations; teacher salaries

\section{Introduction}

According to the Pastoral Note on Education, Results of the KWI Meeting in November 2008, point 8, it was stated that the Catholic Education Institution is one of the Church's works and a form of participation by Catholics in the development of Indonesian society, with three distinct characteristics and core, there are: 1) Faithful efforts to educate the life of the nation, 2) Faithful to the provisions of the church, and 3) Faithful in the noble spirituality) of the founder. And more fundamentally that the Catholic Educational Institution is the Media for the Preaching of the Good News which is characterized by creating a community of school circles inspired by the evangelical spirit; develop and deepen the knowledge gained about the world, so that eventually life and human beings are illuminated by faith so that anyone involved in education is ready to become a leaven of salvation for the community. (NP. Point 4.2). And this is the reason why Catholic families are expected to entrust their children to school at the Catholic Educational Institution.

The presence and role of the LPK has been felt to provide a positive meaning for the development of Indonesian society in urban areas throughout the country, because there is the experience and traditions of the Church, the dedication of missionaries, organizers, managers and implementers which are considered very good and successful in carrying out their tasks quality, and professional governance, visionary in leadership and management. LPK is a reflection of the community about the implementation of quality and character education.

The positive image of Catholic schools has helped lift the image of the Catholic church and opened up public acceptance space for the existence and development of the Catholic church, so that the Church should be proud of this achievement, and it is hoped that the quality and integrity of Catholic education can be maintained so that people remain proud of Catholic education and vying to send their children to school in Catholic schools.

Lately, the growth of public and private education institutions has been fast. The attention of the State is increasingly high in the effort to educate its people in harmony with the mandate of the 1945 Constitution until open access for education to remote areas, plus the interest of 
the private sector outside the increasingly Catholic Church to be involved in the administration of education. As a result of this situation, high and tight competition arises between the organizers of education, which has an impact on the attractiveness of new students through various means of promotion until free schooling.

Responding to this desire, the Archbishop of Medan hoped for up-to-date information before taking a decision towards it, and therefore specifically commissioned the KAM Education Commission and the Foundation Management to sit together and react to it carefully, in accordance with Bishop No. 672 / KD / KA / XI / 1616, November 28, 2016, concerning School Closing and Opening. In accordance with the expectations of the Archbishop of Medan, the Medan Archdiocese Education Commission (EDUCATION OMMISSION-KAM) as an extension of the Bishop's Office in Education, has coordinated with the Foundation Management, to get the data of the schools that the Foundation wants to close and then the KAM Education ommission visit schools are intended to see, hear, and obtain various up-todate information about the existence of the school. The information gathered is a reference for EDUCATION OMMISSION-KAM in submitting Final Recommendations related to the Closing and Opening of said School. EDUCATION OMMISSION-KAM hopes that the latest information gathered from the field will be strong reasons for various parties involved in the implementation of Catholic education, especially the Archbishop of Medan as School Owners get correct and responsible information before a decision is made.

\section{Review of Literatures}

\subsection{Educational Institution}

Educational institution is a public or private educational institution that offers formal education activities ranging from pre-school level to higher education level, both general and special (e.g. religious or special schools). An educational institution is also a social institution that becomes an agent of continued socialization after family institutions.

\section{Types of Education}

1. Formal Education

a. Definition of Formal Education

Formal education is an educational institution carried out by schools ranging from preschool (play group) to tertiary education, both general and specific.

b. Characteristics of Formal Education.

1) Organized in separate classes according to the level.

2) There are age requirements.

3) There is a certain learning period.

4) There is a study time schedule.

5) The learning process is organized in an orderly and structured manner.

6) Materials are arranged based on the curriculum and formulated in the syllabus formally.

7) Learning material is intellectual and continuous academic.

8) Teachers teach using methods, media, and certain teaching sequences.

9) There are report cards, learning evaluations, and diplomas.

10) Schools have an education budget designed for a certain period of time

2. Informal Education (Education in the Family) 
a. Understanding of Informal Education

Informal education is an educational institution carried out by the family. Informal education is rarely realized and lasts a lifetime.

b. Characteristics of Informal Education

1) Not bound by place and time.

2) Not bound by age.

3) Can take place without a teacher and student specifically.

4) Do not use certain methods.

5) Without using a curriculum plan

3. Non-Formal Education

a. Definition of Non-Formal Education

Non-formal education is an educational institution carried out outside the family, such as training courses.

b. Characteristics of Non-Formal Education

1) Programs made in accordance with community needs.

2) The material provided is practical or something that is needed by the community at that time and can soon be fulfilled through short education.

3) The time needed is relatively short.

4) Cost is relatively cheap.

5) The age of participants is different.

6) Class levels do not show clear levels.

7) Implementation of activities is prepared through good planning.

8) The purpose of directed education is to get a job or improve living standards.

9) The time and place of learning is adjusted to those who need it.

10) Generally side by side with formal institutions.

11) Appears because there is a rapid change in society.

\section{Function of Educational Institutions}

1. Manifesto Function of Educational Institutions

According to Horton and Hunt (1996: 34-35), the manifest function of education is to prepare members of society to make a living, develop individual talents for personal satisfaction and for the interests of society, preserve culture, and instill necessary skills for participation in democracy.

2. The Latent Function of Educational Institutions

a. Extend adolescence and delay the transition of the role of children to adulthood.

b. Reducing parental control of their children.

c. Provides a means for insubordination.

d. Maintaining a class system.

\section{Role of Educational Institutions}

According to Robert Dreeben (1968), schools not only teach reading, writing, and counting, but also teach other things such as:

1. Independence

2. Achievement ability

3. Specifications

4. Personality development 


\subsection{Catholic}

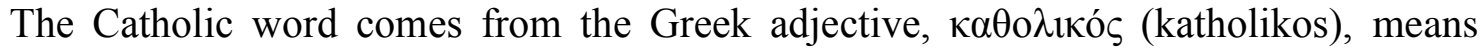
"universal". In the context of Christian ecclesiology, the word Catholic has a rich history of several meanings. For some, the term "Catholic Church" means the Church which is in full communion with the Bishop of Rome, consisting of the Latin Church and 23 Eastern Catholic Churches; this meaning is commonly understood in many countries. For Protestants, the "Catholic Church" or often translated as "the Church of Am" means all people who believe in Jesus Christ throughout the world and all time, regardless of "denomination".

The people of the Eastern Orthodox Church, the Anglican Church, the Lutheran Church and some Methodist Churches believe that their Churches are Catholic, in the sense of the continuity of the original universal Church founded by the apostles. Both the Roman Catholic Church and the Orthodox Church believe that each of its Churches is the only original and universal Church. In "Catholic Christianity" (including the Anglican Communion), bishops are seen as the highest officials in Christianity, as united shepherds in fellowship with the whole Church and in fellowship with one another. Catholicism is considered to be one of the Four Characteristics of the Church. The other three characteristics are One, Holy, and Apostolic, according to the Nicene Creed of 381: "I believe in the one Church, holy, catholic and apostolic."

History of the use of the word "catholic" in the Church

A letter written by Ignatius to Christians in Smyrna [4] around 106 is the oldest surviving evidence regarding the use of the term Catholic Church (Letter to the church in Smyrna, 8). The Catholic Church used Ignatius to call the universal Church in fellowship with the Bishop of Rome (the Pope). Certain heretics at that time, who denied that Jesus was a physical person who truly suffered misery and death, and instead said that "he only seemed to suffer misery" (Letter to the church at Smyrna, 2), was not a Christian true in Ignatius's view. [5] The term Catholic Church was also used in the Martyrdom of Polycarp at 155, and in the Muratorian Fragment, around 177.

St. Cyril of Jerusalem (around 315-386) appealed to those who were receiving the guidance of his Christian faith thus: "If you are in the cities, don't just ask where is the House of God (because other profane sects also try to call places - place of their own God's Houses), don't just ask where the Church is, but ask where the Catholic Church is. Because this is the special name of this Holy Church, our mother, who is the bride of our Lord Jesus Christ, the Only Son Allah "(Catechism Materials, XVIII, 26).

The term Catholic Christianity is contained in the laws of the Roman empire when Theodosius I, the Roman Emperor from 379 to 395, specialized the name for adherents of "the religion taught to the Romans by the holy Apostle Peter, because the religion was preserved thanks to the tradition strong and which is now embraced by Pontif (Pope) Damasus and by Peter, Bishop of Alexandria ... while for others, because according to our judgment they are foolish madmen, we declare that they must be marked as nista as heretics, and may not call their meeting places churches. " This February 27, 380 law is contained in book 16 of the Codex Theodosian. This law confirmed Catholic Christianity as the official religion of the Roman Empire.

The use of the term Catholic to distinguish the "true" Church from heretical groups was also carried out by Augustine who wrote thus:

"In the Catholic Church, there are many other things that are worthy to keep me in his womb. 
The understanding of people and nations keeps me in the Church; so does his authority, confirmed by miracles, fertilized by hope, enlarged by love, and strengthened by age, the succession of the priests made me endure, starting from the throne of the Apostle Peter himself, to whom God, after His resurrection, gave the task to pasture His sheep (Jn 21: 15-19), down to the bishops who are now.

"And so, finally, in the name of Catholicism, which, not without reason, in the midst of so many heretics, has been preserved by the Church, so that even if all heretics want to be called Catholics, if there are foreigners who ask where the Catholic Church is meeting, none of the heretics are able to appoint the chapel or his own house.

"That's how much the number and meaning of the noble bonds that the Christian name has that keep a believer in the Catholic Church, as it should be ... with you, where there are none of these things to lure or hold me back. ... No one can release me from the faith that binds my mind with so many and so strong bonds to Christianity ... On my side, I do not believe in the gospel unless it is moved by the authority of the Catholic Church. "

- St. Augustine (354-430): Against Epistola the Manichaeus, called Fundamental, chapter 4: Evidence of Catholic faith.

\section{Research Methods}

This research is conducted by using descriptive qualitative approach or often called the Naturalistic method because this research is used in natural conditions. Qualitative research usually pursues verbal data that is more representative of phenomena and not numbers filled with percentages and obtained from the field. This research is qualitative because it does not make calculations, statistics, etc., but uses scientific emphasis or research that results in discoveries that are not achieved by statistical procedures or by other means of quantification.

\section{Discussion}

\section{A. Results of Visit in Kindergarten Santo Thomas 2 Medan \\ 1. Data from the Field}

Some up-to-date information that obtained from the results of visit in Kindergarte. Santo Thomas 2 Medan is as follows:

a. Student and Teacher:

- Students number 36 people or 1 class.

- There are 3 teachers, consisting of: 1 of headmaster, and 2 of classroom teacher.

- There is a waste of 1 teacher. It means that the teaching assignments that must be done by one teacher are done by two teachers.

- The available teacher is old enough, and not compact, making it difficult to communicate and good cooperation to think about strategies and ways to advance the school. The Principal complains that there are teachers who are difficult to collaborate with and are often late to attend school. If the bad situation is not immediately addressed, it is difficult for school development to occur, and if it is immediately addressed, it is likely that school development will still occur.

b. School Facilities and Infrastructure:

- School buildings are good, and study chairs are in good condition. Learning activities are still comfortable to do. 
- Facilities play less. This was complained by the Principal and the teacher and had been conveyed to the Foundation, but there was no good attention.

- There is a growth in the surrounding kindergarten / early childhood in a fertile manner with adequate and attractive play facilities for children, so when there is no additional adequate play facilities or adding new facilities in TK. Thomas 2 , the attractiveness of the school is not strong enough to attract children to school.

c. School Financing Sources

Financing operational education in kindergarten Santo Thomas 2 Medan is sourced from tuition charged to students in the amount of Rp. 235,000, - per month plus other periodic quotes in the form of: Development Money of Rp. 1,000,000 - for non-Catholic students and Rp. 900,000,- for students who are Catholics, administration money is Rp. 100,000, and other costs, such as the cost of clothes and other equipment.

With the construction costs quoted from students each year, in fact the costs can be allocated in part for the addition of children's play facilities at the school. Of the total costs collected and if the teacher is reduced, the breakeven is actually found at the costs incurred by the Foundation. This shows that there is no routine expenditure for the school, other than the cost of teacher salaries. The cost of school fees is still enough to pay teachers when there are no more than 2 teachers in the school. While other costs beyond the teacher's salary can still be overcome by the Principal through ways that are considered legitimate.

d. School Complaints

Some of the complaints of the schools gathered are:

- There is no guidance for strengthening the quality of teacher competencies and fostering spirituality from the foundation.

- Supervision visits from the foundation never existed.

- The foundation has never seriously discussed and identified the problems experienced by the school until the proposed school closure is rolling.

e. Hope

The Principal and the Teacher hope that the educational activities in the Kindergarten Santa Thomas 2 can still be done and hopes that the Archbishop of Medan provides an opportunity to improve commitment and cooperation in recruiting students with special supervision and assistance from trusted supervisors. In addition, it needs to be considered for the transfer of teachers or placing new teachers who are strongly committed to advancing schools and can collaborate with students, so that one step is the same in thinking about ways and steps to advance schools, specifically increasing the number of students in the new school year.

\section{The Assessment of Education Commission}

a. School Strength

There are several school strengths in holding educational activities, including:

- The location of the school is in the middle of the city, the location of work for parents is near and can be accessed quickly, making the school has a strong prospect to maintain

- School buildings, chairs and study tables that are still good and decent.

- The number of students classified as sufficient, is proof that there is still public trust in the school. If the trust is maintained and good communication and cooperation with the parents occur, it is still possible for the school to develop and exist.

b. School Weaknesses 
As for some of the weaknesses of schools in holding education, including:

- Inadequate children's play facilities

- Poor teacher communication and collaboration

- Some teachers are often late and excuse me

- Low teacher commitment to school development.

- No supervision from the foundation

- There is no teacher training related to competence and spirituality.

- Principals and teachers do not know the application of the 2013 Curriculum and schools do not have an SOP in the implementation of Kindergarten education.

c. Recommendation of the Commissioner

Looking at the various information gathered in the field, as for the recommendations submitted by the Education commission KAM are as follows:

- Kindergarten. St. Thomas 2 is still worthy of consideration to keep it open.

- The school must be given special assistance (by the foundation) in managing education and designing appropriate student recruitment strategies.

- Teacher performance needs to be evaluated and reduce the number of teachers

- Principals and teachers must receive regular coaching and training.

- Regulate school finance.

\section{B. Results of Visit in Kindergarten Budi Murni 2 Medan}

1. Data from the Field

Some up-to-date information that obtained from the results of visit at kindergarten Budi Murni 2 Medan is as follows:

a. Student and Teacher:

- Students number 48 people or 3 classes. It should be 2 classes.

- There are 6 teacher staff, consisting of: 1 headmaster, and 5 class teachers.

- The teacher is assigned to 1 class 2 people.

- There is a teacher's waste of 3 people. It means that the teaching assignments that must be done by one teacher are done by two teachers. If teacher staff is reduced, then school funding can be overcome.

- The available teacher is old enough, and not compact, making it difficult to communicate and good cooperation to think about ways and strategies to advance the school.

- Teachers complain that the Principal does not involve teachers in setting school policies.

b. School Facilities and Infrastructure:

- School buildings are good, but chairs and study tables need to be repaired. Learning activities can still take place, it's just not so conducive.

- Facilities play enough and need to provide new play facilities.

- There is a growth of the surrounding kindergartens / PAUD with adequate and attractive play facilities for children, so when there is no additional adequate play facilities or adding new facilities in TK. Budi Murni 2 Medan, the attractiveness of the school is not strong enough to attract children to school.

- The location of the school is very far from the crossing road and is proposed to be integrated with the location of Budi Murni Elementary School 2 which is in a strategic place and can be traversed by Transfortasi Umum. In addition, the location of SD Budi 
Munri 2 allows for that. It has been submitted to the foundation, responded well, but has not been realized.

c. School Financing Sources

Financing operational education in kindergarten Budi Murni 2 Medan sourced from school fees charged for students in the amount of Rp. 240,000, - per month plus other periodic quotes in the form of: Development Money of Rp. 650,000, - for non-Catholic students and Rp. 575,000, - for students who are Catholics, Administration money is Rp. 75,000, - and other costs, such as clothes costs $=245,000$ (for three pairs), 90,000 equipment money, book money $=185,000,-$, Magazine Money $=90,000,-$ Pas Photo Money $=20,000,-$ attribute money $/$ connecting book $=30,000$, and pool money $=75,000$

The many types of citations and acknowledged by the school not communicated to the community-saving foundation are very burdensome to parents of students, while many kindergartens around it have low school fees and no other quotes. Some teachers have proposed to evaluate the situation and request a reduction in costs, but the reason has been long and usually done at school, as a strong reason to survive and not reduce it.

From the information provided by the school principal and teacher, that at the beginning of the semester many parents came to find out school information and intended to send their children to school in kindergarten Budi Murni 2 Medan, but after seeing the many types of costs listed in the brochure, the parents retreated and did not send their children there. The Comedian believes that the situation is very alarming and that it happened for quite a long time without the knowledge of the management of the foundation. This is a bad sign of school financial management governance in terms of financial transparency. Serious attention is needed in terms of controlling the correct financial management of schools.

Seeing the condition of chairs, blackboards and other facilities that are very bad, the education commision believes that the development costs for students can actually be used in part to overcome them and each year can continue to be feasible, so that there is seriousness in kindergarten Budi Murni 2 Medan is truly committed to carrying out educational activities for the general public and it is a new attraction for carrying out learning activities in the school.

d. School Complaints

Some of the complaints of the schools gathered are:

- There is no guidance for strengthening the quality of teacher competencies and fostering spirituality from the foundation.

- Supervision visits from foundations never existed.

- The Foundation never talks seriously and identifies the problems experienced by the school until the proposed school closure is rolling.

e. Hope

The principal and the teacher hope that the educational activities are in kindergarten Budi Murni 2 can still be done and hopes that the Archbishop of Medan provides an opportunity to improve commitment and cooperation in recruiting students with special supervision and assistance from trusted supervisors. In addition, it should be considered for teacher transfer, retirement, and placing new teachers who are strongly committed to advancing schools and can collaborate in teams, so that one step in thinking about ways and steps to advance schools, specifically increasing the number of students in the new school year.

\section{Assessment of the Education Commission}

\section{a. School Strength}


There are several school strengths in holding educational activities, the study is:

- The number of students classified as sufficient, is proof that there is still public trust in the school. If the trust is maintained and good communication and cooperation with the parents occur, it is still possible for the school to develop and exist.

- It has been widely known by the community because of the fairly old school age.

- The location of the school is quite large near the residential area.

- Buildings and play facilities can still be used waiting for new improvements and supplies.

b. School Weaknesses

As for some of the weaknesses of schools in holding education, including:

- Many types of cost quotes

- Poor teacher communication and collaboration

- The age of the Principal and some teachers who are old and even retired from KWI

- Teacher commitment is low for school development

- There is no communication and supervision from the foundation

- No teacher development related to competence and spirituality.

c. Recommendation of the Commissioner

Looking at various information gathered from the field, as for the recommendations submitted by the KAM Education commission are as follows:

- Kindergarten. St. Thomas 2 is still worthy of consideration to keep it open.

- The school must be given special assistance (by the foundation) to improve teacher competence and in designing appropriate student recruitment strategies.

- Old teachers must be retired

- The number of teachers on duty must be reduced (according to class availability)

- The principal must be replaced (Already Retired KWI) and sought by someone who is committed to increasing the number of new students.

- Curb school finance, including types of cost quotes.

- Facilities must be addressed.

\section{Results of Visit in Budi Murni Elementary School 4 Percut}

1. Data from the Field

Some of the latest information obtained from the results of visits at Budi Murni 4 Percut Elementary School is as follows:

a. Student and Teacher:

- Students number 171 people, consisting of 6 classes. With details as follows: Class $1=$ 19 people, Class $2=42$ people, Class $3=29$ people, Class $4=30$ people, Class $5=26$ people, and Class $6=25$ people. The number is classified enough and can be seen to be improved if the promotion is carried out by the school.

- The number of teachers is 10 people, consisting of 1 Headmaster and 9 classroom teachers. Among them there is 1 teacher who is approaching retirement.

b. School Facilities and Infrastructure:

- The school building is very good, bright, clean (newly built) using funds from the Deli Serdang Regency Government, for the collaborative effort that was established by the Principal with the Deli Serdang District Education Office.

- The location of the school is in a church environment.

- Learning chairs are in good condition and support the implementation of learning 
activities in school.

c. School Financing Sources

Financing education operations at Budi Murni Elementary School 4 Percut comes from school fees charged for students in the amount of Rp. 100,000, - per month. Another source is BOS funds from the Government, amounting to Rp. 800,000 per student every year. The funds are paid three times a year through school accounts and received in full by the school. Rp. 50,000 , - each month from the BOS funds per student is returned to the parents of the students and the rest is managed by the school.

Another source is the Smart Indonesia Program Scholarship for 23 people were given by the Central Government and the funds were sent to school accounts and managed by the school. Seeing the strategic location of the school and being in the middle of a residential area, the school has the prospect of being developed and special attention is needed in the form of intense socialization to the parents of students by the school and in the supervision or assistance of the school's supervisors.

According to the teachers and principals' admission that there is an additional free tutoring program conducted by the school, but lately it has not been done anymore. At that time there was an increase in the number of students who enrolled at Budi Murni Elementary School 4 Percut, and when it was not implemented again there was a decline in students and switched to other schools in Percut.

\section{Conclusion}

Catholic schools have to be proud because the school buildings are well available and are located in the area of the Catholic Church. The main task of the teacher is to do educational assignments. Even though it is not optimal, the cooperation and commitment of all parties involved, especially the institution and the school parties are needed in terms of designing and realizing various collaborative efforts with the church and parents, so that new students will grow in Catholic schools. There is no good achievement without hard work and sacrifice and also a good work approach strategy. Therefore there must be good meetings that create a positive attitude and a sense of belonging to the school, where if the school is successfully developed, all parties will feel the benefits.

Hopefully the information which gathered by the education commission KAM is addressed as a reflective material to be used as a reference for improvements. And presumably there is an optimistic attitude that there is still a chance to continue to rise from the fall, as long as there is a strong will from all parties to improve attitudes, pursue public interests, and the interests of the Church for the preaching of the good news.

\section{References}

Komdik KWI. 2008. Nota Pastoral Pendidikan Konferensi Wali Gereja Indonesia. Jakarta. YPK.Donbosco. 2015. Dokumen Profil Sekolah. Medan.

McGunnifle Christine \& Hackett Chris. 2015. Spritual and Relegius Capabilities for chatolic Shools. The Confruence of academic Motivation and chatolic educations. Ejurnal of chatolic educational in Australia, vol.2. Issue 1, article 6. Http://researchonline.nd.edu.ay/ecea.

Komdik KWI. 2016. Rubrik penilaian identitas dan karakteristik, standar dan tolok ukur 
pendidikan katolik Indonesia. Pedoman evaluasi diri dan penjaminan mutu pendidikan dasar dan menengah sekolah katolik indonesia. Jakarta.

H. Arief Furchan. 2011. Pengantar Penelitian Dalam Pendidikan. Yogyakarta. Pustaka Pelajar.

Edward Sallis. 2012. Total quality management in education. Manajemen mutu pendidikan. Yogyakarta: IRCiSoD.

Nanang Fattah. 2015. Manajemen Strategik Berbasis Nilai. Bandung: Rosda.

Rivai Veithzal, at el. 2011. Corporate Performance Management. Bogor: Ghalia Indonesia. 